\title{
Discrimination between Seroclearance and Seroconversion in Hepatitis B Using CD4+ CD25+ CD127- FoxP3+ T Regulatory Cells
}

\author{
Jila Masrour-Roudsari1,2, Mohammad Reza Hasanjani Roushan², Yousef Yahyapour², Rahim Barari Savadkoohi², \\ Ali Bijani ${ }^{3}$ and Mousa Mohammadnia-Afrouzi $2,4,{ }^{*}$ \\ 1 MD, Student Research Committee, Babol University of Medical Sciences, Babol, Iran \\ 2 MD, Infectious Diseases and Tropical Medicine Research Center, Health Research Institute, Babol University of Medical Sciences, Babol, Iran \\ ${ }^{3}$ MD, PhD, Social Determinants Research Center, Health Research Institute, Babol University of Medical Sciences, Babol, Iran \\ ${ }_{4}^{4} \mathrm{PhD}$, Department of Immunology, School of Medicine, Babol University of Medical Sciences, Babol, Iran
}

\begin{abstract}
* Corresponding author: Mousa Mohammadnia-Afrouzi, Infectious Diseases and Tropical Medicine Research Center, Health Research Institute, Babol University of Medical Sciences, Babol, Iran. Tel: +981132207924; Email: m.mohammadnia@mubabol.ac.ir, mousamohammadnia@yahoo.com
\end{abstract}

Received 2020 September 21; Revised 2020 0ctober 03; Accepted 2020 October 19.

\begin{abstract}
Background: Hepatitis B is a viral disease that can be chronic. The Treg population during hepatitis appears to have an important role in controlling disease progression.

Objectives: The present study aimed to determine the level of Tregs in patients with chronic hepatitis B (CHB) at different stages of the disease.

Methods: This study was carried out on 90 patients with CHB followed-up for an average of 10 years and divided into hepatitis B surface antigen ( $\mathrm{HBs} \mathrm{Ag}+$ ), seroconverted (HBs Ag- and hepatitis B surface antibody [HBs $\mathrm{Ab}+]$ ), and serocleared (HBs Ag- and $\mathrm{HBs} \mathrm{Ab}-$ ) groups. Then, $5 \mathrm{ml}$ of the blood sample was taken, and the peripheral blood mononuclear cells (PBMCs) were separated using Ficoll. The surface markers, including CD4, CD25, and CD127, and FoxP3 intracellular marker were measured in the PBMCs. Isotype was considered the control for each sample. The samples were read by the FACSCalibur 4-color flow cytometer (BD Biosciences, San Jose, CA, USA) and analyzed using Flowjo software (version 7.6.1). The levels of aspartate aminotransferase, alanine transaminase, $\alpha$-fetoprotein, platelets, white blood cells, and hemoglobin were extracted from the patients' records.

Results: The mean age values of the $\mathrm{HBs} \mathrm{Ag}+(\mathrm{n}=35)$, seroclearance $(\mathrm{n}=27)$, and seroconversion $(\mathrm{n}=28)$ groups were $43.97 \pm 11.86$, $47.26 \pm 12.95$, and $47.39 \pm 10.40$ years, respectively. The frequency of $\mathrm{CD} 4^{+} \mathrm{CD} 25^{+} \mathrm{FoxP} 3^{+}(\mathrm{Treg})$ was higher in the HBs Ag+ group than that reported for the other two groups. The Treg population demonstrated a significant difference between the serocleared and seroconverted groups; however, the Treg frequency was higher in the seroconverted group in comparison to that of the other two groups. The Treg/TActivator ratio was significantly higher in the HBs Ag+ group than those reported for the two other groups.

Conclusion: $\mathrm{CD} 4{ }^{+} \mathrm{CD} 25^{+} \mathrm{FoxP}^{+} \mathrm{T}$ cells are the important subgroups of Treg cells affecting immune suppression.

Keywords: Chronic hepatitis B, Seroclear, Seroconvert, T Regulatory cells
\end{abstract}

\section{Background}

Hepatitis B is a viral disease affecting about 2 billion individuals worldwide among whom 240 million patients have chronic hepatitis $\mathrm{B}$ (CHB) infection. It is more likely to be chronic if younger cases are involved (1). Several factors are effective in the chronicity of hepatitis $\mathrm{B}$. One of these factors is the host immune status $(2,3)$. Effector $\mathrm{T}$ cells, as a part of the cellular immune system, play a significant role in clearing the hepatitis B surface antigen (HBs $\mathrm{Ag}$ ) in acute hepatitis B (4), and the dysfunction of these cells can lead to CHB. In fact, the inhibition of effector cell activity by regulatory cells can be one of the causes of CHB. Given the noticeable changes in the Treg population during hepatitis, these cells appear to play an essential role in controlling disease progression. Therefore, some strategies can be suggested to eliminate the virus from the bloodstream and treat the disease.

In recent years, several studies have proposed different treatments for chronic hepatitis. These studies have demonstrated the role of regulatory $\mathrm{T}$ cells (Tregs) in different types of diseases. Recent evidence has shown that Tregs can block the effect of the immune system on hepatitis B through cell-to-cell contact or secretion of cytokines, leading to chronic disease and preventing the elimination of S-antigen from the patients' blood (5-8). It has also been indicated that the frequency of Tregs in patients with acute hepatitis is similar to that of healthy individuals. However, the frequency of Tregs has a significant increase in patients with chronic hepatitis, compared to that reported for those with acute hepatitis (9-11).

Patients with CHB have very low or indistinguishable levels of T cells. Nevertheless, CD4+ CD25+ Treg cells are at high levels in their peripheral blood. These Tregs express about $5-10 \%$ of CD4. FoxP3 is also a key regulatory gene for the growth and function of Tregs observed in $\mathrm{CD} 44^{+} \mathrm{CD} 25^{+}$more than that in $\mathrm{CD}^{+} \mathrm{CD}^{-} 5^{-}$cells (10). There is no agreement on the high population of $\mathrm{CD}^{+} \mathrm{CD} 25^{+}$ Foxp $^{+}$Tregs in patients with chronic hepatitis in 
most studies. Some researchers consider the frequency of these cells to be different in patients and healthy individuals; however, others consider them equal (12-14). Based on the literature, the measurement of Treg levels at different stages of the disease showed that the levels of these cells in severe chronic hepatitis were much higher than those reported for other stages of the disease. These results indicated that the elevated levels of Tregs could cause immune suppression and chronic diseases (15).

\section{Objectives}

According to some results and given that the chronic hepatitis patients exhibited a different serology during prolonged follow-up, it is hypothesized that the levels of Tregs in these patients might be different at various stages of the disease and result in serologic changes among them. Therefore, the current study aimed to determine the levels of Tregs in CHB patients at different stages of the disease.

\section{Methods}

\subsection{Study subjects}

This cross-sectional study was carried out on 90 patients with CHB followed-up for an average of 10 years and divided into $\mathrm{HBs} \mathrm{Ag}+$, seroconverted (HBs Ag- and hepatitis B surface antibody [HBs $\mathrm{Ab}+])$, and serocleared (HBs Ag- and HBs Ab-) groups. The patients with hepatitis $C$ virus, human immunodeficiency virus, and immunodeficiency, along with patients using antiviral drugs, were excluded from the study. There were 35 (20 males and 15 females), 28 (15 males and 13 females), and 27 (20 males and 7 females) patients in the first (HBs $\mathrm{Ag}+$ ), second (seroconverted), and third (serocleared) groups, respectively. The patients of the present study were within the age range of 21-70 years.

\subsection{Separation of peripheral blood mononuclear cells}

For each patient, $5 \mathrm{ml}$ of the blood was taken in ethylenediaminetetraacetic acid-containing tubes and immediately sent to the Immunology Laboratory of Babol University of Medical Sciences, Babol, Iran. The peripheral blood mononuclear cells (PBMCs) were separated using Ficoll (Inno-train Diagnostic GMBH, Germany) and density gradient centrifugation based on the manufacturer's method. In addition, $1 \times 10^{6}$ cells $/ \mathrm{mL}$ cells were collected from the middle phase.

\subsection{Flow cytometry}

The isolated PBMCs were washed twice using staining buffer (phosphate-buffered saline plus 0.5\% bovine serum albumin).

A 4-color flow cytometry technique was used for the determination of the frequency of Tregs and identification of the cell surface and intracellular markers. The surface markers, including CD4, CD25, and CD127, and FoxP3 intracellular marker were measured in the study. The antibodies for staining markers and isotype controls were purchased (eBiosciences Inc., California, USA), and cell staining was performed according to the manufacturer's instructions. Firstly, $10^{6}$ PBMC and isotype control were stained with antigen-presenting cellconjugated anti-CD4 (RPA-T4), Brilliant Blue 515conjugated anti-CD25 (clone 2A3), and peridinin chlorophyll protein Cy5.5-conjugated anti-CD127 (clone HIL-7R-M21).

After staining the surface markers, the lymphocytes were washed with staining buffer. Subsequently, the surface markers were firstly fixed with fixation and then permeabilized with permeabilization solution (BD Biosciences, San Jose, CA, USA). Afterward, the intracellular marker FoxP3 was stained by phycoerythrin-conjugated anti-FoxP3 (clone 259D/C7). Isotype was considered the control for each sample. Compensation controls were also performed to ensure that each color was read in its own channel. The samples were then read using the FACSCalibur 4-color flow cytometer (BD Biosciences, San Jose, CA, USA) and analyzed using FlowJo software (version 7.6.1).

\subsection{Laboratory tests}

The levels of aspartate aminotransferase, alanine transaminase, $\alpha$-fetoprotein, platelets, white blood cells, and hemoglobin were extracted from the patients' records.

\subsection{Statistical analysis}

Statistical analysis was carried out using SPSS software (version 17). Analysis of variance and t-test were used to compare the lymphocytic markers in different groups. Moreover, a receiver operating characteristic (ROC) curve was applied for diagnostic value, and the area under the curve (AUC) was presented with a $95 \%$ confidence interval (CI).

\section{Results}

The study participants were divided into the three HBs Ag+ $(n=35)$, seroclearance $(n=27)$, and seroconversion $(n=28)$ groups with the mean age values of $43.97 \pm 11.86,47.26 \pm 12.95$, and $47.39 \pm 10.40$ years, respectively. Table 1 tabulates the demographic and laboratory data of the patients. There was no difference in liver function and other laboratory tests among the three groups.

The gated lymphocytes on forward and side scatter were first analyzed for the CD4 marker, and it was observed that there was no significant difference among the three groups in the frequency of this marker $(\mathrm{P}=0.442)$. In addition, the frequency of $\mathrm{CD} 4^{+}$ $\mathrm{T}$ cell subsets was also calculated (Figure 1 ).

The $\mathrm{CD}^{+}{ }^{+} \mathrm{CD}_{25}{ }^{+} \mathrm{FoxP}^{+}$and $\mathrm{CD}^{+}{ }^{+} \mathrm{CD} 25^{+}$FoxP3 


\begin{tabular}{|c|c|c|c|c|}
\hline \multirow{2}{*}{ Variable } & \multicolumn{3}{|c|}{ Group } & \multirow{2}{*}{ P-value } \\
\hline & Seroconverted $(n=28)$ & Serocleared $(n=27)$ & HBs Ag+ $(n=35)$ & \\
\hline $\begin{array}{l}\text { Age (year) } \\
\text { Mean } \pm \text { SD }\end{array}$ & $47.39 \pm 10.40$ & $47.26 \pm 12.95$ & $43.97 \pm 11.86$ & 0.423 \\
\hline $\begin{array}{l}\text { Gender (male) } \\
\text { n (\%) }\end{array}$ & $15(53.6)$ & $20(74.1)$ & $20(57.1)$ & 0.245 \\
\hline $\begin{array}{l}\text { Aspartate aminotransferase (IU/L) } \\
\text { Mean } \pm \text { SD }\end{array}$ & $23.89 \pm 12.88$ & $21.63 \pm 5.83$ & $24.69 \pm 6.28$ & 0.386 \\
\hline $\begin{array}{l}\text { Alanine transaminase (IU/L) } \\
\text { Mean } \pm \text { SD }\end{array}$ & $25.50 \pm 16.08$ & $25.41 \pm 11.64$ & $25.74 \pm 11.80$ & 0.995 \\
\hline Platelets $\left(\times 10^{3} / \mu \mathrm{L}\right)$ & $228 \pm 48$ & $216 \pm 40$ & $242 \pm 64$ & 0.160 \\
\hline$\alpha$-fetoprotein & $2.07 \pm 1.07$ & $2.53 \pm 1.63$ & $2.33 \pm 1.05$ & 0.399 \\
\hline White blood cells $\left(\times 10^{3} / \mu \mathrm{L}\right)$ & $6.8 \pm 1.5$ & $7.4 \pm 1.7$ & $7.7 \pm 1.7$ & 0.099 \\
\hline Hemoglobin (g/dL) Mean \pm SD & $13.5 \pm 1.15$ & $13.7 \pm 1.04$ & $13.23 \pm 1$ & 0.222 \\
\hline
\end{tabular}

populations were calculated to determine Tregs and TActivators. Moreover, the frequency of $\mathrm{CD}^{+} \mathrm{CD}^{+} 5^{+}$ $\mathrm{FoxP}^{+}$(Treg) was higher in the HBs $\mathrm{Ag}+$ group than that of the other two groups $(\mathrm{P}=0.0001)$. The Treg population was demonstrated with a significant difference between the serocleared and seroconverted groups $(\mathrm{P}=0.012)$; however, the Treg frequency was higher in the seroconverted group (Table 2).

Among the calculated subgroups, there was a significant difference in the frequency of the $\mathrm{CD}^{+}$ $\mathrm{CD}^{+} 5^{+} \mathrm{CD} 127^{-}$FoxP3 $^{+}$subgroup among the three groups $(\mathrm{P}=0.0001)$; however, there was no significant difference between the serocleared and seroconverted groups $(\mathrm{P}=0.758)$. The Treg/T-Activator ratio was significantly higher in the HBs Ag+ group than those reported for the two other groups $(\mathrm{P}=0.033)$. Although the difference of this ratio was significant between the serocleared and seroconverted groups, it was higher in the seroconverted group (Table 3 ).

The ROC analyses of $\mathrm{CD}^{+}{ }^{+} \mathrm{CD} 25^{+} \mathrm{FoxP} 3^{+} \mathrm{CD} 127-$ Treg cells showed a significant AUC of 0.768 (CI: 95\%, $\mathrm{P}=0.0001$; Figure 2). Sensitivity and specificity, positive predictive value (PPV), negative predictive value (NPV), and positive and negative likelihood ratio (LR+ and LR-) were calculated for the best corresponding cut-off. The cut-off point was considered 4. The sensitivity, specificity, PPV, and NPV of this value were $76 \%, 70 \%, 60 \%$, and $83 \%$, respectively. For this cut-off, the LR+ and LR- were 2.52 (95\% CI: 1.63-3.90) and 0.34 (95\% CI: 0.18 -
0.63), respectively. According to the result of the ROC curve, Tregs can discriminate between $\mathrm{HBs} \mathrm{Ag}+$ and HBs Ag- patients. Table 4 tabulates the AUC of other CD4+ $\mathrm{T}$ cell subgroups.

A)
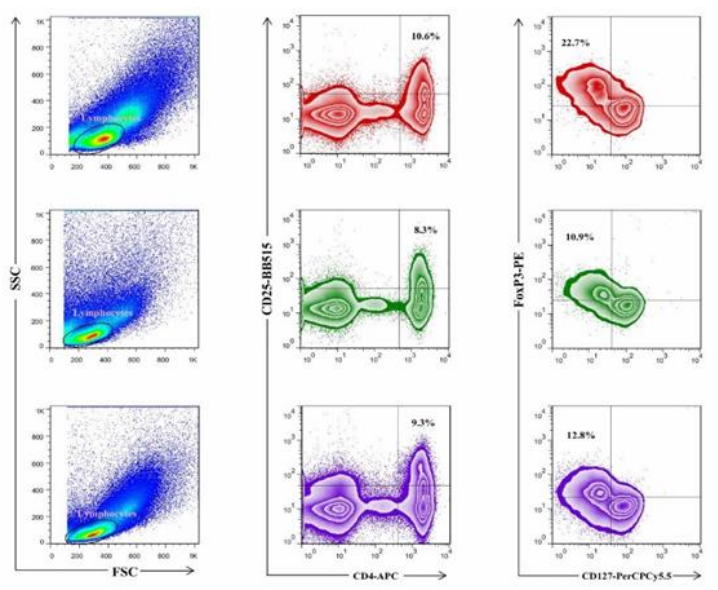

Figure 1. Frequency of regulatory $\mathrm{T}$ cell subpopulations in a hepatitis $B$ surface antigen-positive patient (A), serocleared subject (B), and seroconverted participant (C) analyzed by flow cytometry; staining of freshly isolated peripheral blood mononuclear cells firstly for surface markers of CD4, CD25, and CD127 and then fixing, permeabilizing, and staining for FoxP3 intracellular marker; gating of lymphocytes in this analysis based on forward and side scatter properties; analysis of gated lymphocytes for CD4 and CD25 markers in a zebra plot; gating and analyzing $\mathrm{CD} 44^{+} \mathrm{CD} 25^{+}$cells in a new zebra plot for $\mathrm{CD} 127$ and FoxP3 markers

\begin{tabular}{|c|c|c|c|}
\hline \multirow[b]{2}{*}{$\mathrm{CD}^{+} \mathrm{T}$ cell subpopulation } & \multicolumn{2}{|c|}{ Group } & \multirow[b]{2}{*}{ P-value } \\
\hline & $\begin{array}{c}\text { Seroconverted } \\
\text { (Mean } \pm \text { SD) }\end{array}$ & $\begin{array}{c}\text { Serocleared } \\
(\text { Mean } \pm \text { SD) }\end{array}$ & \\
\hline CD4 $^{+}$cells & $36.23 \pm 12.34$ & $39.4 \pm 8.9$ & 0.283 \\
\hline CD4 $+{ }^{C D} 25^{+}$cells & $9.31 \pm 4.05$ & $8.34 \pm 3.7$ & 0.357 \\
\hline CD4+CD25+CD127- Treg cells & $2.6 \pm 1.1$ & $3.4 \pm 1.3$ & $0.016^{*}$ \\
\hline $\mathrm{CD}^{+}{ }^{\mathrm{CD} 25}+\mathrm{FoxP}^{+}+$Treg cells & $2.32 \pm 1.7$ & $1.3 \pm 1.1$ & $0.012 *$ \\
\hline $\mathrm{CD}^{+}+\mathrm{CD} 25+\mathrm{FoxP}^{+}{ }^{+\mathrm{CD} 127} \cdot$ Treg cells & $0.39 \pm 0.47$ & $0.36 \pm 0.26$ & 0.758 \\
\hline $\mathrm{CD}^{+}{ }^{\mathrm{CD}} 25^{+}{ }^{\mathrm{F}}$ oxP3- activated Teff cells & $6.99 \pm 3.42$ & $7.03 \pm 3.20$ & 0.973 \\
\hline $\mathrm{CD4}^{+} \mathrm{CD}_{25}^{+} \mathrm{FoxP}^{+}+$Treg cells/activated Teff cells ratio & $0.40 \pm 0.4$ & $0.20 \pm 0.12$ & $0.012 *$ \\
\hline
\end{tabular}

SD: Standard deviation

* Significance level at $\mathrm{P}<0.05$ 
Table 3. Frequency of $\mathrm{CD}^{+}{ }^{+}$subpopulations in peripheral blood mononuclear cells of seroconverted, serocleared, and hepatitis B surface antigen-positive patients

\begin{tabular}{|c|c|c|c|c|}
\hline \multirow[b]{2}{*}{$\begin{array}{l}\mathrm{CD}^{+} \mathrm{T} \text { cell } \\
\text { subpopulation }\end{array}$} & \multicolumn{3}{|c|}{ Group } & \multirow[b]{2}{*}{ P-value } \\
\hline & $\begin{array}{c}\text { Seroconverted } \\
\text { (Mean } \pm \text { SD) }\end{array}$ & $\begin{array}{c}\text { Serocleared } \\
(\text { Mean } \pm \text { SD) }\end{array}$ & $\begin{array}{c}\text { HBs Ag+ } \\
\text { (Mean } \pm \text { SD) }\end{array}$ & \\
\hline CD4 $^{+}$cells & $36.23 \pm 12.34$ & $39.4 \pm 8.9$ & $38.37 \pm 6.6$ & 0.442 \\
\hline $\mathrm{CD}^{+}{ }^{\mathrm{C}} \mathrm{CD} 25^{+}$cells & $9.31 \pm 4.05$ & $8.34 \pm 3.7$ & $10.68 \pm 3.9$ & 0.063 \\
\hline CD4+CD25+CD127- Treg cells & $2.6 \pm 1.1$ & $3.4 \pm 1.3$ & $5.5 \pm 4.1$ & $0.0001 *$ \\
\hline $\mathrm{CD} 4^{+}{ }^{\mathrm{CD} 25}{ }^{+} \mathrm{FoxP}^{+}+$Treg cells & $2.32 \pm 1.7$ & $1.3 \pm 1.1$ & $3.25 \pm 2.05$ & $0.0001^{*}$ \\
\hline CD4+CD25+FoxP3+CD127- Treg cells & $0.39 \pm 0.47$ & $0.36 \pm 0.26$ & $1.36 \pm 1.75$ & $0.001 *$ \\
\hline CD4 ${ }^{+}$CD25 ${ }^{+}$FoxP3 - activated Teff cells & $6.99 \pm 3.42$ & $7.03 \pm 3.20$ & $7.42 \pm 3.12$ & 0.839 \\
\hline $\mathrm{CD}^{+}{ }^{+} \mathrm{CD}_{25}{ }^{+} \mathrm{FoxP}^{+}$Treg cells/activated Teff cells ratio & $0.40 \pm 0.4$ & $0.20 \pm 0.12$ & $0.55 \pm 0.75$ & 0.033 \\
\hline
\end{tabular}

HBs Ag+: Hepatitis B surface antigen-positive; SD: Standard deviation

* Significance level at $\mathrm{P}<0.05$

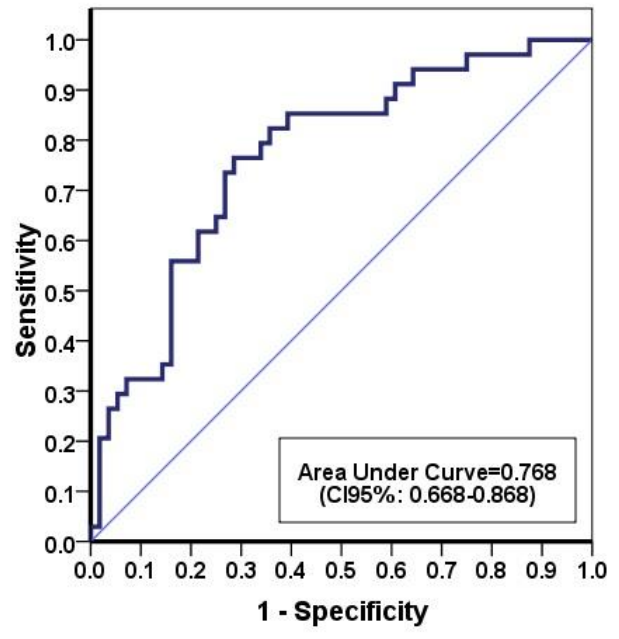

Figure 2. Receiver operating characteristic curve analysis of $\mathrm{CD}^{+}{ }^{+} \mathrm{CD} 25^{+}$FoxP $^{+} \mathrm{CD} 127^{-}$Treg cells

\section{Discussion}

In recent years, the role of $\mathrm{CD} 4^{+} \mathrm{CD} 25^{+} \mathrm{Foxp}^{+}$ Tregs has been increasingly recognized in various diseases, such as viral and autoimmune diseases. Studies have suggested that the frequency of $\mathrm{CD} 4^{+}$ $\mathrm{CD}^{2} 5^{+} \mathrm{FoxP}^{+} \mathrm{T}$ cells significantly increases in patients with chronic hepatitis (16-18). In the present study, the frequency of $\mathrm{CD} 4^{+} \mathrm{T}$ cells in the three groups was measured. Then, the frequency of the subgroups of these T cells was determined, and it was observed that the frequency of $\mathrm{CD}^{+} \mathrm{CD} 25^{+}$ $\mathrm{FoxP}^{+}$subgroup was significantly higher in the HBs $\mathrm{Ag}+$ group than that of the other two groups.

Moreover, although the difference in the frequency of this subgroup was significant in the two HBs Aggroups, it was higher in the serocleared group than that of the seroconverted group. These results are in line with the findings of a study carried out by Jung MK and Shin EC indicating that the frequency of CD4+

\begin{tabular}{|c|c|c|c|}
\hline $\mathrm{CD4}^{+} \mathrm{T}$ cell subpopulations & AUC \pm SE & $95 \% \mathrm{CI}$ & P-value \\
\hline $\mathrm{CD}^{+}$ & $0.522 \pm 0.06$ & $0.404-0.641$ & 0.724 \\
\hline $\mathrm{CD}^{+}{ }^{\mathrm{CD}} \mathrm{C5}^{+}$ & $0.643 \pm 0.06$ & $0.525-0.761$ & 0.023 \\
\hline $\mathrm{CD}^{+}{ }^{\mathrm{CD}} 25^{+}{ }^{+} \mathrm{CD} 127^{-}$ & $0.675 \pm 0.06$ & $0.557-0.794$ & 0.005 \\
\hline $\mathrm{CD}^{+}{ }^{\mathrm{CCD}} \mathbf{5}^{+}{ }^{\mathrm{CD}} 127 \cdot \mathrm{FoxP}^{+}$ & $0.768 \pm 0.05$ & $0.668-0.868$ & 0.0001 \\
\hline
\end{tabular}

$\mathrm{CD}^{2} 5^{+} \mathrm{FoxP}^{+}$Treg cells is higher in chronic HBs Ag+ patients, compared to that reported for those who spontaneously recovered (19).

In the present study, the frequency of $\mathrm{CD} 4{ }^{+} \mathrm{CD} 25^{+}$ $\mathrm{T}$ cells was higher in the $\mathrm{HBs} \mathrm{Ag}+$ group in comparison to that of the two HBs Ag- groups; however, this difference was not significant. The aforementioned finding is in contrast to the results of a study conducted by Badawy et al. demonstrating that this marker had a significant difference between $\mathrm{HBs} \mathrm{Ag}+$ and healthy groups (20). In the positive antigen group of the aforementioned study, this marker was lower in the positive antibody group than that of the negative antibody group indicating that individuals with both positive antigen and positive antibody had a lower immune response.

It cannot be concluded that Tregs result in immune suppression in this group of patients. Furthermore, in the current study, among the two groups of patients with negative antigen, the frequency of Tregs in the positive antibody group was higher than that of the negative antibody group, which is consistent with the results of the study by Badawy et al. Additionally, they observed that the frequency of $\mathrm{CD} 4^{+} \mathrm{CD} 25^{+}$FoxP3 ${ }^{+}$was higher in the CHB group than that reported for the control group showing that the virus could enhance FoxP3 and induce Treg production. In the present study, $\mathrm{CD} 4{ }^{+}$ $\mathrm{CD}_{25}{ }^{+} \mathrm{FoxP}^{+}$was significantly higher in the HBs Ag+ group than that reported for the other two groups.

Some studies have demonstrated that an increase in the number of viruses can boost Tregs (21), suggesting that the higher number of $\mathrm{CD}^{+}{ }^{+} \mathrm{CD} 25^{+}$ $\mathrm{FoxP}^{+}$cells in the HBs Ag+ group than that of the 
two HBs Ag- groups are due to the higher number of viruses. The balance of Tregs and $\mathrm{T}$ activated cells determines the consequence of hepatic inflammation (i.e., chronic active hepatitis, resolution hepatitis, or fulminant hepatitis). Therefore, sustaining and regulating this balance are critical for the immunological manipulation of hepatitis. Some studies have shown that the Treg/T-Activated ratio increases in infectious diseases and does not significantly reduce even after treatment (22), which in the present study was also significantly higher in individuals with $\mathrm{HBs} \mathrm{Ag}+$ than that of the patients with HBs Ag-. However, in the HBs Ag- group, this ratio was higher in the patients with $\mathrm{HBs} \mathrm{Ab}^{+}$, compared to that of those with HBs Ab-.

Based on the results of another study, it was indicated that Tregs prevent the blood from being cleared of the virus. In the aforementioned study, blocking Tregs with antibodies significantly reduced viral load, and it was shown that $\mathrm{T}$ effectors were effective in clearing blood from the virus (23). In the current study, although patients in the HBs Ag+ group were affected for a long time, the high levels of Tregs can be due to the lack of clearance of HBs Ag from the blood of these patients.

\section{Conclusion}

A higher frequency of Tregs was observed in the peripheral blood of CHB patients with $\mathrm{HBs} \mathrm{Ag}+$ in comparison to the subjects with HBs Ag- which may contribute to viral persistence. Although it cannot be concluded that Tregs resulted in immune suppression in CHB patients, the evidence shows that Treg cells suppress $\mathrm{T}$ cell responses directed against the hepatitis viruses. For this reason, Tregs can affect the prognosis of hepatitis B and are responsible for the chronicity of the disease and lack of antibodies. $\mathrm{CD}^{+} \mathrm{CD}^{2} 5^{+} \mathrm{Foxp}^{+} \mathrm{T}$ cells are the major subgroup of Treg cells affecting immune suppression. Therefore, it is required to carry out further studies to demonstrate the exact relationship between Tregs and virus-specific immune responses.

\section{Acknowledgments}

The authors would like to express their gratitude to Minoo Hashemi for her utmost assistance and Evangeline Foronda for the proofreading of the English manuscript.

\section{Footnotes}

Authors' Contribution: M.R.H.R., Y.Y., and R.B.S. designed the study and wrote the manuscript. J.M.R and M.M.A. performed experimental and data analyses and wrote the manuscript. A.B. performed data analysis, prepared the tables, and wrote the manuscript. All the authors read and approved the final manuscript.

Conflict of Interests: The authors declare that there is no conflict of interest.

Ethical Approval: This study was approved by the Ethics Committee of Babol University of Medical Sciences (MUBABOL.REC.1395.157).

Funding/Support: This project was funded by the Vice-Chancellor of Research and Technology of Babol University of Medical Sciences (grant no.: 3785) and extracted from the PhD thesis of Jila Masrour.

Informed consent: Informed consent was obtained from all the individuals who participated in the present study.

\section{References}

1. De Clercq E, Férir G, Kaptein S, Neyts J. Antiviral treatment of chronic hepatitis b virus (HBV) infections. Viruses. 2010; 2(6):1279-305. doi: 10.3390/v2061279.

2. Uyar Y, Cabar C, Balci A. Eroprevalence of hepatitis B virus among pregnant women in Northern Turkey. Hapat Mon. 2009;9(2):146-9.

3. Mohammadizad H, Shahbazi M, Hasanjani Roushan MR, Soltanzadeh-Yamchi M, Mohammadnia-Afrouzi M. TIM-3 as a marker of exhaustion in CD8+ $\mathrm{T}$ cells of active chronic hepatitis B patients. Microb Pathog. 2019;128:323-8. doi: 10.1016/j.micpath.2019.01.026. [PubMed: 30660734].

4. Xue-Song L, Cheng-Zhong L, Ying Z, Mo-Bin W. Changes of Treg and Th17 cells balance in the development of acute and chronic hepatitis B virus infection. BMC Gastroenterol. 2012;12:43. doi: 10.1186/1471-230X-12-43. [PubMed: 22548790].

5. Belloni L, Allweiss L, Guerrieri F, Pediconi N, Volz T, Pollicino T, et al. IFN- $\alpha$ inhibits HBV transcription and replication in cell culture and in humanized mice by targeting the epigenetic regulation of the nuclear cccDNA minichromosome. J Clin Invest. 2012;122(2):529-37. doi: 10.1172/JCI58847. [PubMed: 22251702].

6. Cai D, Mills C, Yu W, Yan R, Aldrich CE, Saputelli JR, et al. Identification of disubstituted sulfonamide Compounds as specific inhibitors of hepatitis B virus covalently closed circular DNA formation. Antimicrob Agents Chemother. 2012;56(8):4277-88. doi: 10.1128/AAC.00473-12. [PubMed: 22644022]

7. Lucifora J, Xia Y, Reisinger F, Zhang K, Stadler D, Cheng X, et al. Specific and nonhepatotoxic degradation of nuclear hepatitis B virus cccDNA. Science. 2014;343(6176):1221-8. doi: 10.1126/science.1243462. [PubMed: 24557838].

8. Tavakolpour S. Inhibition of regulatory cells as a possible cure of chronically hepatitis B virus infected patients. Immunol Lett. 2016;171:70-1. doi: 10.1016/j.imlet.2015.12.007. [PubMed: 26730847]

9. Ye B, Liu X, Li X, Kong H, Tian L, Chen Y. T-cell exhaustion in chronic hepatitis B infection: current knowledge and clinical significance. Cell Death Dis. 2015;6:e1694. doi: 10.038/ cddis.2015.42. [PubMed: 25789969].

10. Aalaei-Andabili SH, Alavian SM. Regulatory T cells are the most important determinant factor of hepatitis B infection prognosis: A systematic review and meta-analysis. Vaccine. 2012;30:5595-602. doi: 10.1016/j.vaccine.2012.06.063. [PubMed: 22781305].

11. Peng G, Li S, Wu W, Sun Z, Chen Y, Chen Z. Circulating CD4+ CD25+ regulatory $\mathrm{T}$ cells correlate with chronic hepatitis $\mathrm{B}$ infection. Immunology. 2008;123(57-65). doi: 10.1111/j.13652567.2007.02691.x. [PubMed: 17764450].

12. Stoop JN, van der Molen RG, Baan CC, van der Laan LJ, Kuipers EJ, Kusters JG, et al. Regulatory $\mathrm{T}$ cells contribute to the impaired immune response in patients with chronic hepatitis B virus infection. Hepatology. 2005;41(4):771-8. doi: 
10.1002/hep.20649. [PubMed: 15791617].

13. TrehanPati N, Kotillil S, Hissar SS, Shrivastava S, Khanam A, Sukriti S, et al. Circulating Tregs correlate with viral load reduction in chronic HBV-treated patients with tenofovir disoproxil fumarate. J Clin Immunol. 2011;31(509-20). doi: 10.1007/s10875-011-9509-7. [PubMed: 21305387].

14. Manigold T, Racanelli V. T-cell regulation by CD4 regulatory T cells during hepatitis $\mathrm{B}$ and $\mathrm{C}$ virus infections: facts and controversies. Lancet Infect Dis 2007;7(12):804-13. doi: 10.1016/S1473-3099(07)70289-X. [PubMed: 18045563].

15. Xu D, Fu J, Jin L, Zhang H, Zhou C, Zou Z, et al. Circulating and liver resident $\mathrm{CD} 4+\mathrm{CD} 25+$ regulatory $\mathrm{T}$ cells actively influence the antiviral immune response and disease progression in patients with hepatitis B. J Immunol. 2006;177(1):739-47. doi: 10.4049/jimmunol.177.1.739. [PubMed: 16785573].

16. Wang R, Xie R,. Circulating regulatory Tfh cells are enriched in patients with chronic hepatitis B infection and induce the differentiation of regulatory B cells. Exp Cell Res. 2018; 365(2):171-6. doi: 10.1016/j.yexcr.2018.02.031. [PubMed: 29501568].

17. Crotty S. T follicular helper cell differentiation, function, and roles in disease. Immunity. 2014;41(4):529-42. doi: 10.1016/j.immuni.2014.10.004. [PubMed: 25367570].

18. Locci M, Havenar-Daughton C, Landais E, Wu J, Kroenke MA, Arlehamn CL, et al. International AIDS vaccine initiative protocol C principal, investigators $\mathrm{PP}$, shane crotty. human circulating PD-1+CXCR3-CXCR5+ memory Tfh cells are highly functional and correlate with broadly neutralizing HIV antibody responses. Immunity. 2013;39(4):758-69. doi: 10.1016/j.immuni.2013.08.031.

19. Jung MK, Shin EC. Regulatory $T$ cells in hepatitis B and C virus infections. Immun Netw. 2016;16(6):330-6. doi: 10.4110/in.2016.16.6.330. [PubMed: 28035208].

20. El-Badawy O, Sayed D, Badary MS, Abd-Alrahman ME, El-Feky MA, Thabit AG. Relations of regulatory T cells with hepatitis markers in chronic hepatitis B virus infection. Human Immunol. 2012;73(4):335-41. doi: 10.1016/j.humimm.2012.01.014. [PubMed: 22342871].

21. Dietze KK, Schimmer S, Kretzmer F, Wang J, Lin Y, Huang X, et al. Characterization of the treg response in the hepatitis $B$ virus hydrodynamic injection mouse model. PLoS One. 2016; 11(3)e0151717. doi: 10.1371/journal.pone.0151717. [PubMed: 26986976].

22. Hasanjani RM, Bayani M, Soleimani AS, Mohammadnia-Afrouzi M, Nouri HR, Ebrahimpour S. Evaluation of CD4+CD25+foxp3+ regulatory $\mathrm{T}$ cells during treatment of patients with brucellosis. J Biol Regul Homeost Agents. 2016;30(3):675-82. [PubMed: 27655484].

23. Kosinska AD, Pishraft-Sabet L, Wu W, Fang Z, Lenart M, Chen J, et al. Low hepatitis $B$ virus-specific t-cell response in males correlates with high regulatory $\mathrm{T}$-cell numbers in murine models. Hepatology. 2017;66(1):69-83. doi: 10.1002/hep.29155. [PubMed: 28295453]. 